\title{
Faktor-Faktor Keberhasilan Program Promosi Kesehatan “Gempur Stunting" Dalam Penanganan Stunting di Puskesmas Rancakalong Sumedang
}

\author{
TATANG MANGGALA, JENNY RATNA SUMINAR, HANNY HAFIAR
}

Program Magister Ilmu Komunikasi, Universitas Padjadjaran

Email: manggalatatang@gmail.com, Tel: 081294658183

Abstrak

Pemerintah Indonesia menetapkan 60 Kabupaten/Kota prioritas penanganan stunting. Berdasarkan penetapan tersebut Sumedang masuk dalam kabupaten prioritas dikarenakan pada tahun 2018 angka prevalensi stunting mencapai angka 32\%. Penjaringan yang dilakukan Bappeda Sumedang terdapat 10 Desa di Sumedang yang angka prevalensi stuntingnya tergolong tinggi dan tiga diantaranya adalah desa-desa di Rancakalong. Untuk mengatasi hal tersebut puskesmas Rancakalong menggagas Program Promosi Kesehatan "Gempur Stunting" yang telah berhasil menurunkan angka prevalensi stunting dari $27,7 \%$ menjadi $19,8 \%$ sehingga menjadikannya sebagai program promosi kesehatan teladan. Penelitian ini dilakukan untuk mengetahui faktorfaktor keberhasilan promosi kesehatan "Gempur Stunting". Hasil penelitian menunjukkan bahwa menurunkan angka prevalensi stunting tertinggi di Sumedang dikarenakan adanya faktor-faktor pendukung diantaranya: (1) Variasi kegiatan yang berbasis masyarakat; (2) Kolaborasi dan koordinasi yang baik antar sektor terkait dan (3) Sustanibilitas program promosi kesehatan gempur stunting.

Kata Kunci : Stunting, program promosi kesehatan, komunikasi kesehatan

The Indonesian government has set 60 priority districts/cities for stunting handling. Based on this determination, Sumedang is included in the priority district because in 2018 the stunting prevalence rate reached 32\%. The selection conducted by Bappeda Sumedang contained 10 villages where the prevalence rate of stunting was high and three of them were villages in Rancakalong. To overcome this, the Rancakalong Community Health Center initiated the "Gempur Stunting" Health promotion Program which has succeeded in reducing the prevalence of stunting from $27.7 \%$ to $19.8 \%$, making it an exemplary health promotion program. This research was conducted to determine the success factors of the "Gempur Stunting" health promotion. The results showed that reducing the highest stunting prevalence rate in Sumedang was due to the following supporting factors: (1) variations in community-based activities; (2) Good collaboration and coordination between related sectors, and (3) Reliability of the stunting-fighting health promotion program.

Keywords: Stunting, health promotion program, health communication

Vol. 11, No. 2, Hal 88-98

Maret 2021

Fakultas Ilmu Komunikasi, Universitas Pancasila 



\section{PENDAHULUAN}

Isu stunting merupakan isu global khususnya di negara-negara miskin dan berkembang termasuk Indonesia (Mitra, 2015). Data dari Kementerian Kesehatan menunjukkan persentase stunting terus meningkat dari tahun 2014-2018. Pada tahun 2014 mencapai angka 28,9\% meningkat hingga tahun 2018 menjadi 30,8\% (Kementrian Kesehatan, 2018). Angka ini masih lebih tinggi dari target WHO yang menetapkan angka stunting harus di bawah 20\%. Isu stunting merupakan masalah yang kompleks yang disebabkan oleh banyak faktor, diantaranya adalah minimnya pengetahuan masyarakat tentang gejala, ciri-ciri dan pencegahan stunting itu sendiri. Masyarakat sering kali tidak mengetahui stunting, di mana perawakan pendek pada anak kerap kali dianggap normal padahal dampak stunting pada fungsi neurokognitif memiliki konsekuensi yang menghancurkan (Onis\&Branca,2016). Anak-anak yang terhambat memiliki otak yang kerdil dan menjalani kehidupan yang kerdil, menghambat perkembangan seluruh masyarakat. Besarnya dampak stunting membuat pemerintah Indonesia mencanangkan beberapa program intervensi untuk pencegahan dan penanganan stunting secara terintegrasi dengan melibatkan lintas kementerian dan lembaga.

Adapun salah satu daerah dari 60 kabupaten/kota yang menjadi prioritas untuk penanganan stunting adalah Kabupaten Sumedang. Hal ini dikarenakan angka stunting di Kabupaten Sumedang berada di atas rata-rata nasional dan Jawa Barat. Pada tahun 2018, angka stunting di Kabupaten Sumedang mencapai 32 persen, dengan kata lain dari 100 bayi di Sumedang, 32 orang mengalami stunting. Pemerintah Kabupaten Sumedang pun menargetkan permasalahan terkait dengan stunting dapat turun hingga 17 persen pada tahun 2023 (Manggala, 2020).

Badan Perencanaan Pembangunan, Penelitian, dan Pengembangan Daerah (Bappeda) Kabupaten Sumedang melakukan riset pada tahun 2019 tentang Penentuan Lokus Prioritas Penanganan Stunting di Kabupaten Sumedang dengan Pendekatan Kajian Risiko Adaptasi Perubahan Iklim. Salah satu hasilnya adalah perankingan terkait dengan desa yang paling rentan terkena stunting. Hasil riset tersebut menyatakan bahwa terdapat 35 desa yang sangat rentan terhadap kejadian stunting di Kabupaten Sumedang. Dari riset tersebut diperoleh data bahwa terdapat tiga desa dari Kecamatan Rancakalong yang masuk dalam daftar tersebut. Desa-desa tersebut adalah Desa Cibungur, Pangadegan, dan Sukasirnarasa yang mana angka prevalensi stunting-nya mencapai $27,7 \%$.

Berdasarkan hal itu, Puskesmas Rancakalong menggagas Program Promosi Kesehatan Gempur Stunting (Puring). Pada Penjaringan balita stunting bulan Februari dan Agustus 2019, angka prevalensi stunting di Rancakalong berhasil melandai ke angka 19,8\% di bawah batas yang ditetapkan WHO sebesar 20\%. Hal itu menjadikan Rancakalong tercatat sebagai kecamatan dengan penurunan tertinggi, terbukti pada tanggal 13 Desember 2019 Program Promosi Kesehatan Gempur Stunting (Puring) diminta dipresentasikan di Provinsi Jabar untuk jadi percontohan kabupaten atau kota lain di Jawa Barat.

Promosi kesehatan yang dilakukan oleh Penyuluh Kesehatan Puskesmas Rancakalong merupakan tanggungjawab bersama antara petugas, pengunjung, dan masyarakat. Penyuluh Kesehatan Puskesmas sudah sepatutnya menjadi teladan perilaku sehat di masyarakat dan melahirkan gerakan pemberdayaan masyarakat termasuk dalam menanganai persoalan stunting (Manggala, 2020). Upaya promosi kesehatan yang dilakukan oleh Penyuluh Kesehatan Puskesmas Rancakalong ini juga menjadi tanggungjawab pemerintah kabupaten/kota dan kecamatan beserta jajaran sektor terkait untuk memfasilitasi puskesmas agar dapat melaksanakan promosi kesehatan.

Promosi kesehatan bukan hanya sebuah proses penyadaran individu maupun masyarakat atau peningkatan pengetahuan di bidang kesehatan saja, tapi juga merupakan sebuah program kesehatan yang telah dirancang untuk memperbaiki perubahan perilaku kesehatan masyarakat (Setyabudi \& Dewi, 2017). Pemilihan Puskesmas Rancakalong Kabupaten Sumedang sebagai subjek penelitian dikarenakan program promosi kesehatan yang dilakukan dianggap salah satu yang terbaik di Jawa Barat karena berhasil dalam menekan prevalensi stunting.

Berdasarkan latar belakang di atas, penelitian ini bertujuan untuk mengetahui faktor-faktor 
keberhasilan program promosi kesehatan Gempur Stunting yang dilakukan oleh Penyuluh Kesehatan Puskesmas Rancakalong sehingga dapat menurunkan prevalensi stunting mencapai angka tertinggi di Sumedang.

\section{TINJAUAN PUSTAKA}

Stunting merupakan kondisi gagalnya pertumbuhan (growth faltering) pada anak akibat akumulasi ketidakcukupan nutrisi yang berlangsung lama mulai dari kehamilan sampai usia 24 bulan (Hoffman, Sawaya, Verreschi, \& Tucker, 2000) (Bloem, et al., 2013). Kondisi ini diperburuk dengan tidak terimbanginya kejar tumbuh (catch up growth) yang memadai (Kusharisupeni, 2002). Indikator yang digunakan untuk mengidentifikasi balita stunting adalah berdasarkan indeks tinggi badan menurut umur (TB/U), menurut standar WHO child growth standart dengan kriteria stunting jika nilai $\mathrm{z}$ score $\mathrm{TB} / \mathrm{U}<-2$ Standard Deviasi (SD) (Picauly \& Magdalena, 2013). Periode 0-24 bulan merupakan periode yang menentukan kualitas kehidupan sehingga disebut dengan periode emas. Periode ini merupakan periode yang sensitif karena akibat yang ditimbulkan terhadap bayi pada masa ini akan bersifat permanen dan tidak dapat dikoreksi. Untuk itu diperlukan pemenuhan gizi yang benar pada usia ini (Mucha, 2012).

Program promosi kesehatan adalah hasil dari upaya dan kerja yang disengaja oleh sekelompok orang atau organisasi untuk menangani masalah kesehatan di komunitas, sekolah, institusi kesehatan, atau tempat kerja (Fertman \& Allensworth, 2010). Sementara itu menurut Setyabudi \& Dewi (2017) promosi kesehatan merupakan sebuah program kesehatan yang telah dirancang untuk memperbaiki perubahan perilaku kesehatan masyarakat.

Program Gempur Stunting atau "Puring" adalah program yang diinisiasi oleh Penyuluh Puskesmas Rancakalong sebagai upaya untuk menurunkan dan mencegah stunting. Program ini terdiri dari berbagai kegiatan, diantaranya adalah $\mathrm{KIA} / \mathrm{KB}$, gizi, remaja, kesling, promkes, imunisasi dan sektor terkait seperti KUA, KB, dinas pendidikan, muspika, dan desa.
Program Gempur Stunting "Puring" merupakan implementasi dari kerangka penanganan stunting Kecamatan Rancakalong yaitu intervensi gizi spesifik dan intervensi gizi sensitif. Intervensi gizi spesifik berkontribusi $30 \%$, ditujukan kepada anak dalam 1.000 Hari Pertama Kehidupan (HPK) dan kegiatan ini dilakukan oleh sektor kesehatan. Sedangkan intervensi gizi sensitif berkontribusi $70 \%$, ditujukan dengan berbagai kegiatan pembangunan di luar sektor kesehatan. Sasarannya adalah masyarakat umum dan tidak khusus untuk 1.000 HPK.

Dalam rencana aksi intervensi percepatan penurunan stunting Kecamatan Rancakalong tahun 2018 dan 2019, peran Puskesmas Rancakalong adalah sebagai berikut:

1. Peningkatan Pendidikan Gizi

a. Praktek pengasuhan gizi pada ibu dan anak melalui PMBA;

b. Strategi komunikasi perubahan perilaku masyarakat.

2. Pemberian Suplementasi Gizi

a. Penyediaan makanan tambahan untuk ibu hamil KEK dan balita kurus;

b. Suplementasi TTD dan Vitamin A.

3. Penguatan Surveilan Gizi

a. Surveilan gizi melalui Eppgbm dan validasi kasus masalah gizi.

4. Penjaringan Ibu hamil resiko tinggi;

5. Penjaringan neonatal resiko tinggi;

6. Reproduksi remaja dan calon pengantin;

7. Sosialisasi penjaringan sekolah;

8. Focus Group Discussion tentang pemanfaatan dana desa;

9. Pemicuan CTPS (Cuci Tangan Pakai Sabun).

Tujuan dari program "Puring" ini adalah untuk menurunkan dan mencegah kejadian balita stunting di Kecamatan Rancakalong. Kegiatan yang dilakukan dalam Program "Puring" meliputi:

1. Penjaringan balita stunting melalui BPB pada bulan Agustus 2019;

2. Validasi sasaran balita stunting;

3. Profiling balita stunting untuk melihat penyebab;

4. Menganalisa penyebab masalah yang didapatkan;

5. Menyusun rencana tindak lanjut kegiatan;

6. Melaksanakan kegiatan;

7. Mengevaluasi kegiatan yang telah dilakukan. 


\section{METODE}

Metode penelitian yang digunakan adalah metode kualitatif melalui pendekatan studi kasus dengan teknik penentuan informan multisources. Kriteria informan dalam penelitian ini meliputi: (1) Pencetus Program Promosi Kesehatan Gempur Stunting; (2) Penyuluh Kesehatan di Puskesmas Rancakalong; (3) Masyarakat selaku kelompok sasaran program promosi kesehatan; dan (4) Sektor-sektor yang terkait atau terlibat dalam pelaksanaan program promosi kesehatan gempur stunting.

Teknik pengumpulan data dilakukan melalui wawancara mendalam, studi literatur, observasi dan dokumentasi. Selanjutnya peneliti melakukan analisis data yaitu analisis data dilakukan setelah data berupa transkrip hasil wawancara dan observasi, maupun gambar, foto, catatan harian subjek dan sebagainya yang dirasa lengkap dan sudah sempurna. Peneliti selaku instrumen kunci pada penelitian ini melakukan analsis data dikarenakan hanya peneliti sendiri yang mengetahui secara mendalam semua realitas yang diteliti.

Pengujian data pada penelitin ini meliputi uji credibility (validitas internal), transferability (validitas eksternal), dependability (reliabilitas), dan confirmability (obyektivitas).

\section{HASIL DAN PEMBAHASAN}

Banyak faktor yang mengakibatkan tingginya prevalensi stunting. Penyebab langsungnya bisa karena kurangnya asupan makanan dan adanya penyakit infeksi (Mitra, 2015). Faktor lainnya yaitu pola asuh yang salah, sanitasi, hygiene yang buruk dan rendahnya pelayanan kesehatan. Di samping itu masyarakat belum menyadari anak pendek merupakan suatu masalah, karena di masyarakat dianggap sebagai anak-anak dengan aktivitas yang normal (Unicef Indonesia, 2013).

Itulah yang terjadi di Kecamatan Rancakalong. Pada awal penjaringan balita stunting yang dilakukan oleh Bappeda Sumedang pada tahun 2018 angka prevalensi stunting di Rancakalong mencapai 27,7\%. Menyikapi hal tersebut Puskesmas Rancakalong menggagas program promosi kesehatan. Hal itu sejalan dengan apa yang disampaikan oleh Setyabudi \& Dewi (2017) bahwa promosi kesehatan merupakan sebuah program kesehatan yang telah dirancang untuk memperbaiki perubahan perilaku kesehatan masyarakat. Atas dasar itulah Puskesmas Rancakalong menggagas program promosi Kesehatan untuk merubah perilaku kesehatan masyarakat Rancakalong terkait isu stunting.

Sebagaimana telah disebutkan sebelumnya, program promosi kesehatan adalah hasil dari upaya dan kerja yang disengaja oleh sekelompok orang atau organisasi untuk menangani masalah kesehatan di komunitas, sekolah, institusi kesehatan, atau tempat kerja (Fertman \& Allensworth, 2010). Oleh karenanya, puskesmas Rancakalong membuat program promosi kesehatan "Gempur Stunting" untuk menangani masalah stunting di Rancakalong.

Program promosi kesehatan "Gempur Stunting" merupakan program yang diinisiasi oleh Penyuluh Puskesmas Rancakalong sebagai upaya untuk menurunkan dan mencegah stunting. Program ini terdiri dari berbagai kegiatan, diantaranya sosialisasi dan penyuluhan terkait stunting, membangun kemitraan, Bulan Penimbangan Balita (BPB), Pemberian Makanan Tambahan (PMT) dan sebagainya.

Pada bulan agustus 2019, dilakukan penimbangan balita untuk mengetahui up date angka prevalensi stunting di Rancakalong. Diperoleh data yang mengejutkan dikarenakan angka prevalensi stunting Rancakalong berhasil turun ke angka $19.8 \%$. Angka ini berada di bawah ambang batas prevalensi stunting yang ditetapkan oleh WHO yaitu sebesar 20\% (Aryastami \& Tarigan, 2017).

Dengan melandainya angka prevalensi stunting di Rancakalong menjadi 19,8\% merupakan indikator berhasilnya program promosi kesehatan "Gempur Stunting". Hasil penelitian menunjukkan ada beberapa faktor yang membuat program promosi kesehatan Gempur Stunting (Puring) berhasil menurunkan angka prevalensi stunting tertinggi di Sumedang yaitu: (1) Adanya variasi kegiatan berbasis masyarakat; (2) Terjalinya kolaborasi dan koordinasi yang baik antar sektor; dan (3) Sustanibilitas program. 
Tabel 1. Prevalensi Stunting Agustus 2019

\begin{tabular}{c|c|c|c|c|c}
\hline DESA & $\begin{array}{c}\text { Sasa- } \\
\text { ran }\end{array}$ & $\begin{array}{c}\text { Sgt } \\
\text { Pdk }\end{array}$ & $\begin{array}{c}\text { Pen- } \\
\text { dek }\end{array}$ & Jml & $\%$ \\
\hline Nagarawangi & 333 & 18 & 68 & 86 & 25,8 \\
\hline Cibunar & 175 & 5 & 30 & 35 & 20 \\
\hline Pangadegan & 341 & 12 & 61 & 73 & 21,4 \\
\hline Sukahayu & 313 & 8 & 37 & 45 & 14,4 \\
\hline Sukamaju & 347 & 8 & 48 & 56 & 16,1 \\
\hline Pamekaran & 215 & 15 & 32 & 47 & 21,9 \\
\hline Rancakalong & 238 & 13 & 45 & 58 & 24,4 \\
\hline Sukasinarasa & 247 & 22 & 36 & 58 & 23,5 \\
\hline Cibungur & 235 & 3 & 27 & 30 & 12,8 \\
\hline Pasirbiru & 300 & 8 & 48 & 56 & 18,7 \\
\hline Jumlah & $\mathbf{2 7 4 4}$ & $\mathbf{1 1 2}$ & $\mathbf{4 3 2}$ & $\mathbf{5 4 4}$ & $\mathbf{1 9 , 8}$ \\
\hline \multicolumn{5}{c}{ Sumber: Observasi Penelitian 2020}
\end{tabular}

Faktor keberhasilan yang pertama adalah variasi kegiatan pada program promosi kesehatan Gempur Stunting yang berbasis masyarakat. Program promosi kesehatan yang efektif mencerminkan kebutuhan individu dari populasi prioritas serta latar belakang politik, sosial, etnis, ekonomi, agama, dan budaya masyarakat sekitar (Fertman \& Allensworth, 2010). Trend saat ini di bidang promosi kesehatan menekankan program berbasis masyarakat yang menggunakan berbagai intervensi sebagai strategi utama untuk mencapai perubahan perilaku kesehatan masyarakat (Merzel \& D’Afflitti, 2003).

Menurut Blackburn (1993), program kesehatan berbasis masyarakat terintegrasi dan komprehensif, tidak terbatas pada pengaturan perawatan medis saja, secara sistematis melibatkan para pemimpin komunitas, jaringan sosial, kampanye komunikasi massa, dan pendidikan langsung dari populasi masyarakat. Program berbasis masyarakat menggunakan banyak intervensi, menargetkan perubahan di antara individu, kelompok, dan organisasi (Elder, Schmid, Dower, \& Hedlund, 1993).

Dalam menyusun kegiatan-kegiatan pada program promosi kesehatan gempur stunting, diperlukan strategi komunikasi dalam penyusunannya. Strategi komunikasi merupakan serangkaian kegiatan yang diawali dengan riset dan diakhiri dengan evaluasi yang diterapkan pada lingkungan tertentu (Smith, 2005). Strategi komunikasi juga bisa disebut sebagai panduan dari perencanaan komunikasi dan manajemen untuk mencapai suatu tujuan.
Gambar 1. Tahapan Strategi Komunikasi dalam Menyusun Kegiatan Program Promosi Gempur Stunting

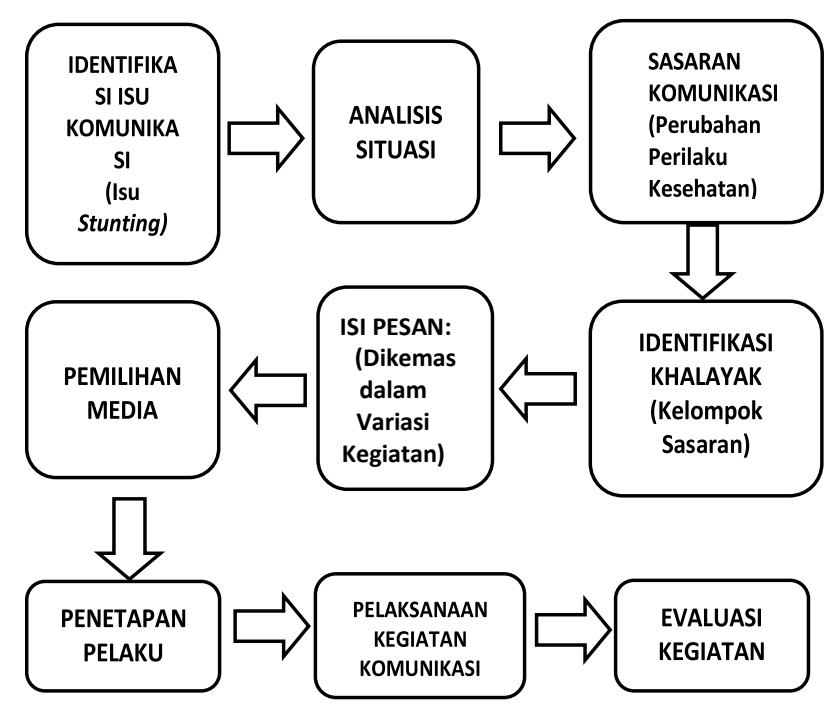

Sumber: Olahan Peneliti 2020

Isu komunikasi yang dimaksud dalam konteks penelitian ini ialah isu stunting di Kecamatan Rancakalong. Setelah didapat gambaran mengenai isu komunikasi, selanjutnya adalah melakukan analisisi situasi yaitu memahami dan merinci kondisi internal dan eksternal puskesmas Rancakalong selaku lembaga yang terkait dalam pelaksanaan kegiatan. Sasaran komunikasi yang dimaksudkan adalah tujuan yang ingin dicapai yaitu terjadinya perubahan perilaku kesehatan masyarakat Rancakalong sehingga terjadinya penurunan angka stunting. Sementara itu identifikasi khalayak dilakukan dengan menetapkan kelompok sasaran program yang dibagi menjadi tiga kelompok sasaran yakni primer, sekunder dan tersier (Jalal, 2018).

Tabel 2. Kelompok Sasaran Program Promkes "Gempur Stunting”

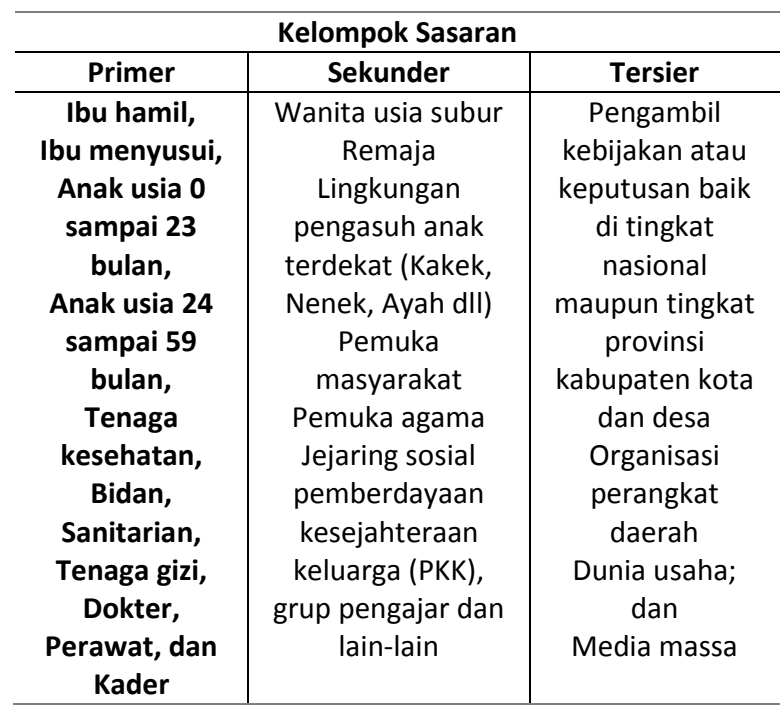

Sumber: Hasil Peneliti 2020 
Adapun kegiatan pesan-pesan yang disampaikan dalam program promosi kesehatan gempur stunting dikemas dalam kegiatan-kegiatan yang bervariasi. Hasil penelitian menjukakan setidaknya ada sembilan kegiatan dalam program promosi kesehatan gempur stunting.

Tabel 3. Variasi Kegiatan Program Promkes Gempur Stunting

\begin{tabular}{l|c}
\hline \multicolumn{1}{c}{ Kegiatan Program Promkes Gempur Stunting } \\
\hline \multicolumn{1}{c}{ Variasi Kegiatan } & Pelaksana \\
\hline “Rancaklong Berbagi" & Kecamatan \\
\hline $\begin{array}{l}\text { Lomba Senam Pencegahan } \\
\text { Stunting }\end{array}$ & $\begin{array}{c}\text { Puskesamas } \\
\text { Rancakalong }\end{array}$ \\
\hline Sosialisasi dan Penyuluhan & $\begin{array}{c}\text { Penyuluh } \\
\text { Kesehatan }\end{array}$ \\
\hline Pelatihan-pelatihan & Dinkes dan Pergizi \\
\hline Kelas Ibu Hamil & Bidan Desa \\
\hline Senam Lansia & Kader \\
\hline $\begin{array}{l}\text { Akademi Keluarga Jabar } \\
\text { Juara Kelas 1000 HPK di } \\
\text { Desa Sukahayu }\end{array}$ & Kecamatan \\
\hline Pemberian Dana Sosial & Pemkab \\
\hline Serbu Desa & Baznaz \\
\hline \multicolumn{2}{c}{ Sumber: Hasil Penelitian 2020 }
\end{tabular}

Manfaat mendasar kegiatan promosi kesehatan dengan menyesuaikan dengan realitas masyarakat telah menerima banyak pengakuan dari berbagai pihak. Salah satunya mengakui bahwa kegiatan promosi kesehatan berbasis masyarakat dapat mempengaruhi kemampuan individu untuk meningkatkan kesehatan mereka sendiri (Davies \& Macdonald, 2002). Begitu pula manfaat dari kegiatan-kegiatan program promosi kesehatan Gempur Stunting telah dirasakan oleh masyarakat Rancakalong berdasarkan observasi di lapangan yang bisa dibuktikan dengan semakin banyaknya partisipan yang terlibat dalam kegiatan-kegiatan tersebut.

Kaitan dengan media komunikasi pada program promosi kesehatan Gempur Stunting, penggunaan media dilakukan dengan tatap muka langsung dan dengan media. Media atau saluran komunikasi adalah cara atau peralatan yang digunakan untuk menyampaikan pesan kepada penerima pesan. Media tersebut dapat berupa surat, telepon atau tatap muka langsung (Pratminingsih, 2006).

Saluran komunikasi dengan menggunakan media langsung tatap muka adalah penggunaan saluran komunikasi melalui aktivitas komunikasi dalam konteks promosi kesehatan di mana aktivitas komunikasi tersebut biasa disebut sebagai pemberdayaan masyarakat. Menurut Said (2011:64) pemberdayaan masyarakat ialah suatu upaya atau proses untuk menumbuhkan kesadaran, kemauan, dan kemampuan masyarakat dalam mengenali, mengatasi suatu hal dalam rangka meningkatkan kesejahteraan mereka sendiri.

\section{Gambar 2. Saluran Komunikasi Program Promosi Gempur Stunting}

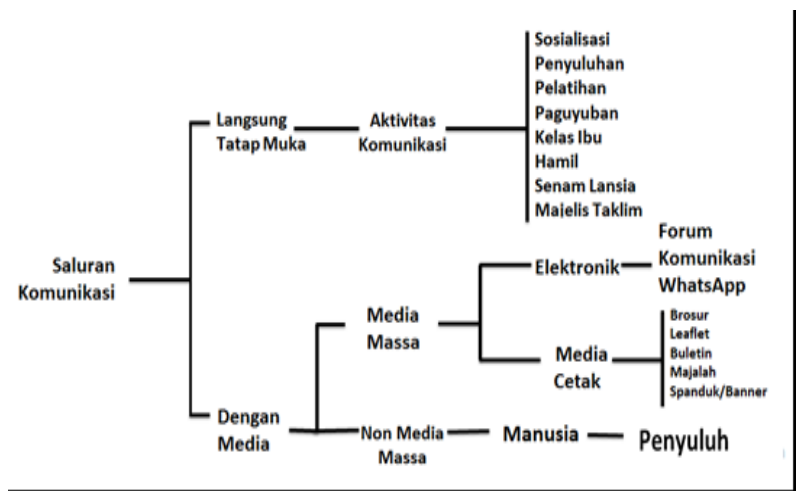

Sumber: Olahan Peneliti 2020

Adapun media massa yang digunakan untuk penyebaran informasi terkait stunting dalam promosi kesehatan Gempur Stunting terdiri dari media cetak dan media elektronik. Untuk media massa cetak menggunakan brosur leaflet, buletin, baliho dan banner, sementara media elektronik terdiri dari internet yang didalamnya menggunakan media sosial untuk penyebarluasan informasi terkait stunting.

Menurut Turnip (2018) dalam penelitiannnya yang berudul "Narration in Health Communication for Stunting" mengatakan bawah sejumlah media komunikasi dan informasi digunakan untuk menyampaikan informasi atau pesan persuasif terkait stunting. Media-media itu dapat membantu masyarakat memahami stunting dan bagaimana mencegah atau mengatasinya. Sementara menurut Hall et al dalam penelitiannya yang berudul "Addressing Communications Campaign Development Challenges to Reduce Stunting in Indonesia", mengatakan bahwa penyebaran informasi stunting melalui media massa telah berhasil meningkatkan opini publik tentang stunting dan secara positif memengaruhi pengambilan keputusan dalam perumusan kebijakan. 


\section{Gambar 3. Proses Pemberdayaan Program Promosi Gempur Stunting}

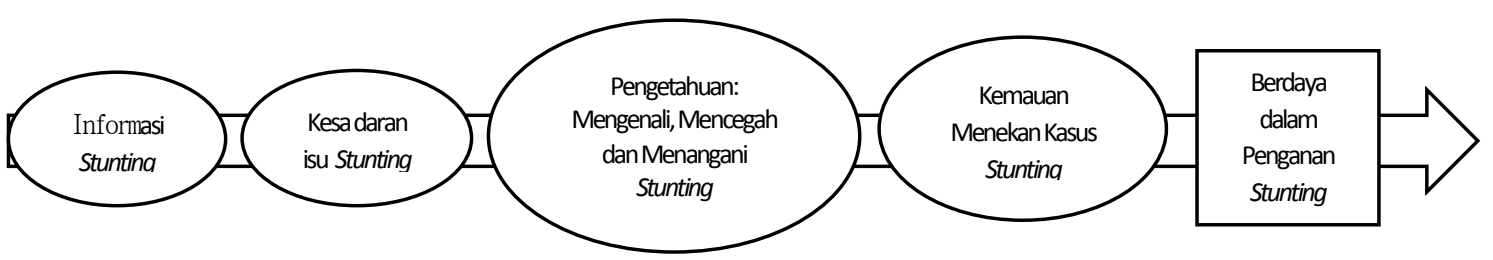

Sumber: Olahan Peneliti 2020

Berdasarkan hasil temuan peneliti, pemberdayaan masyarakat merupakan salah satu kegiatan komunikasi dalam program promosi kesehatan Gempur Stunting yang dilakukan oleh Penyuluh Kesehatan Puskesmas Rancakalong dengan tujuan masyarakat dapat mengenali dan mengetahui, mengatasi dan mencegah gejala stunting.

Menurut Bapak Cheru penyuluh kesehatan puskesmas Rancakalong ketika diwawancarai mengatakan bahwa proses komunikasi dalam pemberdayaan masyarakat terkait stunting ada lima tahap; (1) Penyampaian informasi kesehatan terkait stunting; kemudian, (2) timbul kesadaran kesehatan di masyarakat terhadap stunting; lalu masyarakat (3) memperoleh pengetahuan terkait stunting; dan masyarakat (4) memiliki kemauan kesehatan dalam hal ini adalah kemamuan untuk mencegah stunting atau menerapkan hidup sehat dalam rangka mencegah stunting; dan pada akhirnya sampai pada tahap terakhir yaitu (5) berdaya dalam mengenali, menanganai dan mencegahan stunting.

Untuk melaksanakan lima tahapan tersebut, tahapan kegiatan pemberdayaan masyarakat adalah dengan melakukan kegiatan-kegiatan yang termasuk ke dalam pemberdayaan masyarakat seperti sosialisasi, penyuluhan, pelatihan, paguyuban, kelas ibu hamil, senam lansia, majelis taklim dan lain-lain.

Begitu pula dengan penyebaran informasi terkait stunting di wilayah Rancakalong telah berhasil menimbulkan kesadaran akan pentingnya isu stunting dikarenakan adanya penyebaran terkait informasi stunting melalui leaflet atau brosur, buletin dan spanduk stunting ke desa-desa di wilayah Rancakalong.

Faktor keberhasilan program promosi kesehatan Gempur Stunting yang kedua adalah kolaborasi dan koordinasi antar lintas sektoral. Kolaborasi antar sektor dalam sebuah program kesehatan berhasil mempengaruhi perubahan perilaku individu maupun komunitas terhadap suatu isu kesehatan yang sedang dicanangkan (Corbin, 2017).

Koordinasi dan kolaborasi antarsektoral bisa disebut sebagai kemitraan. Kemitraan adalah upaya untuk melibatkan berbagai sektor, kelompok masyarakat, lembaga pemerintahan maupun bukan pemerintah, untuk bekerja sama dalam mencapai suatu tujuan bersama berdasarkan atas kesepakatan prinsip dan peranan masing-masing (Said, 2011). Kemitraan yang efektif menghasilkan sinergi yang saling melengkapi keterampilan, sumber daya, persfektif dan pengetahuan bersama (Corbin, Jones, \& Barry, 2016).

Hasil penelitian mengungkap bahwa penyuluh kesehatan puskesmas Rancakalong dalam melaksanakan program promosi kesehatan Gempur Stunting menjalin kemitraan dengan beberapa pihak diantaranya Pemerintah Kecamatan Rancakalong, Pemerintah Kabupten, Dinas Kesehatan, dan Baznas. Sementara dari Masyarakat terdiri atas kelompok masyarakat, paguyuban, kelompok agama, dan karang taruna. Sedangkan yang dari Non Pemerintahan ada persatuan ahli gizi di Kabupaten Sumedang dan UIN Sunan Gunung Djati Bandung serta Perusahaan Telkomsel yang turut andil dalam melakukan pencegahan stunting.

\section{Gambar 4. Kemitraan pada Program Promosi} Kesehatan Gempur Stunting

\begin{tabular}{|c|c|c|}
\hline $\begin{array}{l}\quad \frac{\text { PEMERINTAH }}{\text { Dinas Kesehatan Kab. }} \\
\text { SMD } \\
\text { Pemerintah Kab. SMD } \\
\text { Pemerintah Kecamatan } \\
\text { Pemerintah Desa }\end{array}$ & & $\begin{array}{l}\quad \stackrel{\text { NON- }}{ } \frac{}{\text { PEMERINTAH }} \\
\text { Telkomsel } \\
\text { Persatuan Ahli } \\
\text { Gizi }\end{array}$ \\
\hline$\frac{\text { KELOMPOK \& TOKOH }}{\text { MASYARAKAT }}$ & $\begin{array}{c}\text { KEMITRAAN } \\
\text { PUSKESMAS } \\
\text { RANCAKALONG }\end{array}$ & \\
\hline $\begin{array}{l}\text { Paguyuban Taawangsa } \\
\text { Kader, PKKdan } \\
\text { Posyandu } \\
\text { Majelis Ta'lim Al- } \\
\text { Hidayah } \\
\text { Pengajar }\end{array}$ & & $\begin{array}{l}\frac{\text { AKADEMISI }}{\text { UIN }} \\
\text { Sunan Gunung } \\
\text { Djati }\end{array}$ \\
\hline
\end{tabular}

Sumber: Olahan Peneliti 2020 
Untuk bentuk konkrit kegiatan kemitraan dengan pemerintah kabupaten ialah dengan adanya penyaluran dana sosial sebesar Rp40 juta untuk penanganan stunting di Rancakalong. Sementara bentuk konkrit kegiatan kemitraan bersama pemerintah kecamatan adalah lahirnya kegiatan bakti sosial "Rancakalong Berbagi" dan penandatanganan komitemen SAKIP (Sistem Akuntabilitas Kinerja Pemerintah Desa). Bentuk konkrit kegiatan sebagai hasil dari kemitraan bersama Baznas Kabupaten Sumedang, yakni dengan melaksanakan kegiatan bernama "Serbu Desa" yang diadakan di wilayah kecamatan Rancakalong. Kegiatan itu dilakukan memberikan makanan tambahan kepada 50 balita yang terkena stunting di Rancakalong. Bentuk konkrit kemitraan dengan Telkomsel adalah berupa pemberian Tablet kepada desa-desa yang memiliki rasio stunting masih tinggi di wilayah Kecamatan Rancakalong. Perangkat itu akan mendukung upaya aparat kesehatan di desa untuk digitalisasi informasi terkait penanganan dan pencegahan stunting. Sementara bentuk kegiatan kemitraan bersama Persatuan Ahli Gizi Sumedang dalam rangka penanganan stunting di wilayah kecamatan Rancakalong.

Persatuan Ahli Gizi Sumedang melakukan Pelatihan Penyelenggaraan Makanan Lokal dan Balita Stunting serta Pelatihan Pemantauan Pertumbuhan Anak bagi Kader TPPKK Desa yang diadakan di Puskesmas Rancakalong. Kegiatan tersebut merupakan Pengabdian Kepada Masyarakat (PKM). Sedangkan bentuk kegiatan kemitraan dengan UIN Sunan Gunung Djati salah satunya adalah pengenalan dan pendampingan pemanfaatan kefir susu untuk pencegahan stunting yang dilaksanakan di Desa Pasir Biru Kecamatan Rancakalong.

Kemitraan yang terjalin antar lintas sektor dalam program promosi kesehatan dijalin dengan koordinasi yang baik. Hal ini dikarenakan memenuhi indikator suksesnya suatu koordinasi (Salamah \& Rustiana, 2010) sebagai berikut: (1) Terciptanya kesatuan tindakan antar sektor. Dalam Penanganan Stunting di Kecamatan Rancakalong, semua sudah seirama dan satu tindakan dan melaksanakannya maka koordinasi yang dilakukan oleh Penyuluh Kesehatan Puskesmas Rancakalong bersama pihak-pihak tersebut dikatakan berhasil dan sesuai dengan apa yang telah diharapkan. (2) Pelaksanaan program berjalan lancar. Program promosi kesehatan
Gempur Stunting berjalan dengan lancar. Pelaksanaan promosi kesehatan Gempur Stunting berjalan dengan lancar dan sesuai dengan apa yang diharapkan adalah sebuah bukti nyata bahwa koordinasi yang telah dilakukan dengan berbagai pihak terkait sudah sesuai dengan harapan sudah berjalan dengan baik dan bisa dikatakan koordinasi tersebut sukses.

Faktor keberhasilan program promosi kesehatan Gempur Stunting yang ketiga adalah sustainibilatas program promosi kesehatan Gempur Stunting. Menurut Carl \& Diane, (2010):

"Keberlanjutan program sangat
penting. Dalam sebuah kegiatan,
suatu program harus efektif dan
berkelanjutan untuk menerima
dukungan dan sumber daya yang
berkelanjutan dan meningkatkan
dampak. Meskipun ada contoh
program yang berkelanjutan memiliki
bukti bahwa mereka tidak efektif,
program promosi kesehatan
memerlukan keterampilan dalam
mempertahankan dan menjalankan
program yang efektif".

Berdasarkan hasil penelitian ada beberapa kegiatan dalam program promosi kesehatan yang dilakukan secara secara terus menerus sehingga dikatakan sebagai program kesehatan berkelanjutan. Kegiatan tersebut diantaranya: (1) Bulan Penimbangan Balita (BPB); (2) Komitemen SAKIP (Sistem Akuntabilitas Kinerja Pemerintah Desa); dan (3) Pemberian Makanan Tambahan (PMT).

Sebagaimana telah disebutkan sebelumnya bahwasannya ketika pertama kali melakukan penjaringan balita stunting itu dilakukan melalui Bulan Penimbangan Balita (BPB). Kegiatan BPB dilakukan setiap enam bulan sekali atau bisa dikatakan dua kali dalam setahun. Pada pelaksanaannya kegiatan ini dilakukan dengan melaksanakan pengukuran terhadap tinggi badan dan berat badan balita sehingga bisa dipakai untuk memantau progres setiap balita yang ikut pada kegiatan ini apakah balita tersebut tinggi badan atau berat badannya stagnan atau bertambah. Kegiatan Bulan Penimbangan Balita masih dilakukan hingga sekarang untuk mencegah terjadinya kasus baru stunting di wilayah kecamatan Rancakalong, karena tidak menutup kemungkinan akan muncul kasus baru yakni di 
mana terdapat balita dengan tinggi badan atau berat badan yang masuk ke dalam kategori stunting.

Kegiatan kedua yang masih terus berjalan hingga saat ini adalah Komitmen SAKIP. Komitemen SAKIP merupakan suatu sistem yang akuntabel terintegrasi dan sistematis sebagai upaya untuk mengukur kinerja pemerintah Desa dalam melaksanakan pembangunan dan pemberdayaan yang bertujuan untuk meningkatkan kualitas hidup dan kehidupan untuk kesejahteraan masyarakat. Di dalam SAKIP Desa terdapat satu pilar berupa Perjanjian Kinerja (PK) yang mana sasaran utamanya itu adalah komitmen untuk meningkatkan upaya pencegahan stunting. Karena Komitmen SAKIP ini merupakan sebuah komitmen yang harus dijalankan oleh setiap pemerintahan desa yang ada di wilayah kecamatan Rancakalong maka kegiatan ini sejatinya berlangsung secara berkelanjutan hingga sekarang karena langsung dipantau oleh kecamatan Rancakalong.

Kegiatan ketiga yang masih berlangsung hingga saat ini adalah Pemberian Makanan Tambahan (PMT). Kegiatan pemberian makanan tambahan masih terus dilaksanakan hingga saat ini di wilayah kecamatan Ranckalong. Kegiatan pemberian makanan tambahan ini dilaksanakan dengan memberikan makanan tambahan kepada balita di wilayah kecamatan Rancakalong dan kepada ibu yang hamil maupun ibu yang menyusui supaya kandungan ataupun balita yang disusui bisa mendapatkan nutrisi dan gizi yang baik. Pemberian makanan tambahan ini menjadi salah satu program yang berkelanjutan dan berlangsung hingga saat ini karena pemberian makanan tambahan merupakan suatu langkah penting yang menangani termasuk langkah preventif adalah langkah untuk mencegah terjadinya kasus baru stunting di wilayah kecamatan Rancakalong. Adapun pelaksanaan kegiatan pemberian makanan tambahan ini bekerja sama dengan beberapa sektor terkait seperti Dinas Kesehatan Kabupaten Sumedang dan Baznas.

Menurut peneliti program promosi kesehatan Gempur Stunting yang dilakukan oleh Penyuluh Kesehatan Puskesmas Rancakalong menjadikannya sebagai program yang berkelanjutan. Hal tersebut dikarenakan dukungan terus mengalir terhadap pelaksanaan program tersebut dan sumberdaya yang tergabung di dalam pelaksanaan program tersebut adalah sumber daya yang terampil. Program kesehatan yang berfokus pada perilaku individu perlu untuk dipertahankan menjadi sebuah program yang berkelanjutan mengingat dampaknya yang sangat bermanfaat untuk banyak orang akan tetapi membutuhkan sumber daya dan dukungan yang berkelanjutan pula. Promosi kesehatan Gempur Stunting yang dilakukan oleh Penyuluh Kesehatan Puskesmas Rancakalong merupakan program yang berkelanjutan karena program tersebut memiliki tujuan untuk merubah perilaku kesehatan masyarakat Rancakalong untuk berperilaku hidup sehat dalam upaya Penanganan dan pencegahan stunting di Kecamatan Rancakalong.

\section{SIMPULAN}

Berdasarkan hasil riset yang dilakukan oleh Badan Perencanaan Pembangunan, Penelitian, dan Pengembangan Daerah (Bappeda) Kabupaten Sumedang pada tahun 2019 tentang Penentuan Lokus Prioritas Penanganan Stunting di Kabupaten Sumedang dengan Pendekatan Kajian Risiko Adaptasi Perubahan Iklim, hasilnya adalah perankingan terkait dengan desa yang paling rentan terkena stunting. Hasil riset tersebut menyatakan bahwa terdapat 35 desa yang sangat rentan terhadap kejadian stunting di Kabupaten Sumedang. Dari riset tersebut diperoleh data bahwa terdapat tiga desa dari Kecamatan Rancakalong yang masuk dalam daftar tersebut. Desa-desa tersebut adalah Desa Cibungur, Desa Pangadegan, dan Desa Sukasirnarasa yang mana angka prevalensi stunting-nya mencapai $27,7 \%$.

Untuk mengatasi kondisi tersebut Penyuluh Kesehatan Puskesmas Rancakalong kemuadian berinisiatif untuk membentuk sebuah Program Promosi Kesehatan "Gempur Stunting" di mana program ini merupakan sebuah program berkelanjutan yang di dalamnya terdapat kegiatan-kegiatan yang ditujukan sebagai upaya pencegahan dan penangan stunting di Kecamatan Rancakalong.

Pada penjaringan bulan Februari dan Agustus 2019, angka prevalensi stunting di Rancakalong berhasil melandai ke angka $19,8 \%$ di bawah ambang batas yang ditetapkan oleh WHO sebesar $20 \%$. Pencapaian ini menjadikan Rancakalong tercatat sebagai kecamatan dengan penurunan angka prevalensi stunting tertinggi di Sumedang. Keberhasilan ini pula yang menjadikan program promosi kesehatan Gempur Stunting mendapatkan apresiasi yakni pada tanggal 13 Desember 2019, program promosi kesehatan Gempur Stunting (Puring) diminta dipresentasikan di Provinsi Jabar untuk jadi 
percontohan kabupaten atau kota lain di Jawa Barat.

Hasil penelitian mengungkapkan bahwa keberhasilan program promosi kesehatan Gempur Stunting sehingga berhasil menurunkan angka prevalensi stunting tertinggi di Sumedang dikarenakan adanya faktor-faktor pendukung diantaranya: (1) Adanya variasi kegiatan yang berbasis masyarakat; (2) Terjalinya kolaborasi dan koordinasi yang baik antar sektor terkait; dan (3) Sustainibilitas program promosi kesehatan gempur stunting.

\section{DAFTAR PUSTAKA}

Aryastami, \& Tarigan. (2017). Kajian Kebijakan dan Penanggulangan Masalah Gizi Stunting di Indonesia. Buletin Penelitian Kesehatan, 45 (4), 233-240.

Blackburn. (1983). Research and demonstration projects in community cardiovascular disease prevention. J Public Health Policy, 4, 398-422.

Bloem, Pee, Hop, Khan, NC, Laillou, et al. (2013). Key strategies to further reduce stunting in Southeast Asia: Lessons from the ASEAN countries workshop. Food and Nutrition Bulletin, 34 (2).

Corbin, J. H. (2017). Health promotion, partnership and intersectoral action. Health Promotion International, 32(6), 923-929.

Corbin, J. H., Jones, J., \& Barry, M. M. (2016). What makes intersectoral patnership for health promotion work? A review of the international literature. Health Promotion International, 426.

Davies, J. K., \& Macdonald. (2002). Quality, Evidence and Effectiveness in Health Promotion. New York: Routledge.

Elder, Schmid, Dower, \& Hedlund. (1993). Community heart health programs: components, rationale, and strategies for effective interventions. J Public Health Policy, 43, 463-479.

Fertman, \& Allensworth. (2010). Health Promotion Programs. Amerika: Jossey Bass.

Hoffman, Sawaya, Verreschi, \& Tucker. (2000). Why are nutritionally stunted children at increased risk of obesity? Studies of metabolic rate and fat oxidation in shantytown children from São Paulo, 71, 702-715.

Jalal, F. (2018). Intervensi Komunikasi Perubahan Perilaku Untuk Pencegahan Stunting: Pola Konsumsi, Pengasuhan, Higenis Pribadi dan Lingkungan. Jakarta: Widakarya Nasional Pangan Dan Gizi XI.

Kementrian Kesehatan. (2018). Buletin Jendela Data dan Informasi Kesehatan, Pusat Data dan Informasi.

Kusharisupeni. (2002). Peran status kelahiran terhadap stunting pada bayi : sebuah studi prospektif. Jurnal Kedokteran Trisakti, 73-80.

Manggala, T. (2020). Model Promosi Kesehatan Dalam Pencegahan Stunting (Studi Kasus g Program Promosi Kesehatan Penanganan Stunting oleh Puskesmas Rancakalong Sumedang melalui Program Gempur Stunting "Puring"). Jatinangor: Program Magister Ilmu Komunikasi Universitas Padjadjaran.

Merzel, C., \& D'Afflitti, J. (2003). Reconsidering Community-Based Health Promotion: Promise, Performance, and Potential. Public Health Matters, 93 (4), 557-574.

Mitra. (2015). Permasalahan Anak Pendek (Stunting) dan Intervensi untuk Mencegah Terjadinya Stunting (Suatu Kajian Kepustakaan). Jurnal Kesehatan Komunitas, 254-261.

Mucha. (2012). Implementing Nutrition-Sensitive Development: Reaching Consensus. Dipetik August 30, 2020, dari www.bread.org:www.bread.org/institute/pape $\mathrm{rs} /$ nutrition-sensitive-interventions

Onis, \& Branca. (2016). Childhood stunting: a global perspective. Maternal \& Child Nutrition, 12-26.

Picauly, \& Magdalena. (2013). Analisis determinan dan pengaruh stunting terhadap prestasi belajar anak sekolah di Kupang dan Sumba Timur, NTT. Jurnal Gizi dan Pangan, 8 (1), 5562.

Pratminingsih, S. A. (2006). Komunikasi Bisnis (Edisi Pertama). Yogyakarta: Graha Ilmu.

Said, R. (2011). Strategi Promosi Kesehatan Meningkatkan Partisipasi KB Pria di BKKBN Provinsi Sulawesi Selatan. 
Salamah, \& Rustiana. (2010). Meningkatkan Mutu Pelayanan Medik Melalui Koordinasi Antar Unit dan Profesionalisme Petugas (Studi pada RSU Dr. Slamet - Garut). Garut: Universitas Garut.

Setyabudi, \& Dewi. (2017). Analisis Strategi Promosi Kesehatan dalam Rangka Meningkatkan Kesadaran Hidup Sehat oleh Rumah Sakit Jiwa Daerah Dr. RM. Soedjarwadi Provinsi Jawa Tengah. Jurnal Komunikasi, 12 (1), 81-100.
Smith, D. R. (2005). Startegic Planning For Public Relation. Second Edition. London: Lawrence Erlbaum Associates Publisher.

Turnip, S. (2018). Narration in Health Communication for Stunting. Journal of Health Promotion and Behavior, 3 (4), 248-256.

Unicef Indonesia. (2013). Ringkasan Kajian Gizi Ibu. Dipetik August 30, 2020, dari www.unicef.org:http://www.unicef.org 